\title{
Two corrections to recent censuses of the Gutenberg 42-line bible
}

\author{
Luz M. Rangel \\ Department of Design \\ Universidad Iberoamericana \\ 01219-Ciudad de Mexico, Mexico \\ luz.rangel@ibero.mx
}

\author{
Aureli Alabert \\ Department of Mathematics \\ Universitat Autònoma de Barcelona \\ 08193-Bellaterra, Catalonia \\ Aureli.Alabert@uab.cat
}

August 25, 2021

\begin{abstract}
In this note we address two mistakes contained in two important censuses of the extant copies of the Gutenberg 42-line bible. The mistakes have to do with the so-called "increase of edition" that took place when the printing work had already started, entailing that a number of pages had to be composed twice, and producing clearly different outputs. In summary, the mistakes involve the copies known as V2 and P24, today in the Huntington and the Widener Libraries, respectively, and amount to a misclassification of some pages concerning the composition setting to which they belong.
\end{abstract}

Keywords: Gutenberg 42-line bible, increase of edition, Huntington Library, Widener Library.

\section{Introduction}

It is well known that some pages of the Gutenberg 42-line bible were composed twice, due to a decision to increase the total print run, taken at some point after the printing works had started. The print run initially planned and the percentage by which it was increased is not known today with certainty. One of the goals of the authors' current research is to try to quantify, by statistical means, that percentage of increase, using the number of pages of each composition setting in the surviving copies of the book.

To this end, we have proceeded to study carefully the available censuses of the 42-line bible that also include details about the setting of each of the pages featuring two versions. We took as the starting base the censuses by Paul Schwenke [20] (1923) and Paul Needham [9] (1985).

The first one is already very old and can be considered obsolete today, in that new copies and fragments have appeared since then, and other copies have been studied in more detail. But it is to our knowledge the first census containing a systematic table with the setting of each of the relevant pages, thus allowing a quick summary and a first estimate, that locates the increase of edition in roughly 30\%. Needham's 72-page article [9] is an exhaustive study on the paper supply used in different stages of the printing work, and contains another such table, with many of their entries examined personally by the author.

There exist several other good censuses, notably by Seymour de Ricci 1911 [4], Ilona Hubay 1979 [6], and the recent monograph by Eric M. White 2017 [22]. White's beautiful book contains, among other things, the most complete compilation published so far on the history 
of all known copies, either complete or incomplete, including copies with unknown current location, "notional copies" (known to have existed but never seen later), doubtful reports and "ghost" copies, as well as single pages, and fragments of pages.

White's census is therefore the newest and the one to be taken as a reference today. Once we obtained the book, we proceeded to compare Needham's and White's censuses, since we already knew of one mistake contained in Needham's, and suspected of a second one. However, we found that White still reproduces both. Therefore, we decided to take a closer look.

Comparing the same page of different copies it is not difficult to tell if they are from the same or different setting. However, it is not surprising that some misclassifications or transcript errors persist over time. Directly examining all copies is not an easy task, because they are scattered world wide, and most of them are not digitised nor easily available for consultation. It is therefore possible that some classification mistakes still remain to be discovered.

Getting to the point, the mistakes we are talking about involve the copies denoted as V2 and P24 in Needham's scheme (followed closely also by White), corresponding to the books currently belonging to the Huntington Library, in San Marino (California), and to the Widener Library of the Harvard University, in Cambridge (Massachusetts). The first one, printed in vellum, only lacks two leaves, whereas the second, in paper, is one of the twenty complete copies preserved today. It is stated in both Needham's and White's censuses that pages 5 recto, 5 verso and 6 recto of the second quire of the second volume in V2 are from the second setting, when they are in fact from the first; and that the same pages in P24 feature the first setting when they are actually from the second.

The fact that exactly the same pages are involved in both errors may surprise the reader at first. But this is easily understood once some details about the making of the book, and in particular the increase of edition, are exposed. We will devote the next section to briefly explain these details for the reader's convenience. We refer the reader to chapter 2, The Work of the Books, of White [22], and the references therein, notably Needham [9] [8], and Schwab et al. [18], for a more complete account.

In Section 3, we address the peculiarities of the central sheet in quire II-2 and put forward the hypothesis that a shortage of paper supply could have been the reason that its first three pages were not completed within the first composition round. In Section 4, the case of the two abovementioned copies is explained, and we also conclude that the two mistakes have in fact a common origin.

\section{The printing work and the increase of edition}

Thanks to the technology of moveable types, the printing of the 42-line bible (B42, for short) was the first big-scale production of a book. By no means it was an improvised inspiration of someone. Many experiments were possibly undertaken by Johannes Gutenberg at least since his return to Mainz in 1448, but most probably since his previous years in Strasbourg. Indeed, some minor printing works were done in parallel, or shortly afterwards, the printing of the B42; some authors still believe some works could predate the B42, as the Sybillenbuch, several editions of the Latin grammar Donatus, and the astronomical calendar of $1448^{1}$. In any case, Gutenberg had enough to show for convincing Fust, towards the end of 1449, to provide the means for a more ambitious project. The actual printing work, according to several indicators, started around January 1452.

\footnotetext{
${ }^{1}$ See Rangel [10, table 8], or [11, pages 412-420], for a complete list of documents printed in Mainz, in the period 1445-1460, with attributed author.
} 
Although our knowledge of Gutenberg's early life and education background is blurry, it is accepted that he belonged to a patrician family from his father's side, was nevertheless encouraged to learn a trade, had a good education (including Latin language), and shared house with professional coinmakers (from whom he might have learned the punch-cutting and metal casting techniques). Also, he possibly got a bachelor's degree from Universität Erfurt, where he might have developed a motivation to improve the traditional hand copy of textbooks, and where he could meet other people that later became printers themselves. There are many sources providing details (certain or hypothetical) of Gutenberg's personal life and of his historical context. See also [10] or [11, pages 70-79] for a Gutenberg genealogy tree, updated from that of [13].

Taking into account these facts, we must believe that the printing of the B42 was a very well prepared enterprise: From the design of the typefaces and the diagramming of the page layout (contributed by calligrapher Peter Schöffer), to the construction of the hand mould and the printing press, the organization of the work, and the commercial commitment promoted by Fust.

The final product of the Gutenberg workshop was a complete collection of bounded quires. The binding of a whole book, and the finishing details (initial illuminated letters, headlines, chapter numbers, ... ) were done elsewhere, at the expense of the buyer of the book, and by the artisan of his choice. Due to its huge physical size, the bibles were usually bound in two volumes (in some cases, even three or four). Conceptually, and for the sake of a consistent notation, in the literature the quires are assigned to volume I or volume II in a fixed manner. The 65 individual quires are denoted I-1 to I-33, and II-1 to II-32, comprising from Epistola Hieronimi to the Psalmi in the first volume, and from the Proverbia to the Apocalypsis in the second.

Most of the quires were made of five sheets or bifolia (whole pieces of paper), comprising ten leaves, for a total of twenty pages, see Figure 1 . Within a quire, pages are denoted by the number of its leaf, together with an ' $\mathrm{r}$ ' for the recto page or a ' $\mathrm{v}$ ' for the verso page. Thus, the natural reading order of a quire is $1 \mathrm{r}, 1 \mathrm{v}, 2 \mathrm{r}, 2 \mathrm{v}, \ldots, 10 \mathrm{r}, 10 \mathrm{v}$. The full notation for a page comprises the volume, the quire, the leaf, and the ' $r$ ' or ' $v$ ' specification. For instance, II-15-2v refers to the fourth page of quire 15 of the second volume.

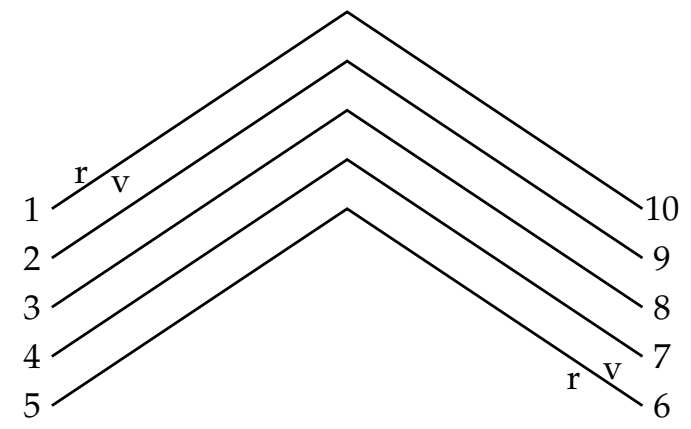

Figure 1: A typical quire of five sheets, and their corresponding leaves (numbered in the natural reading order), each comprising two pages: the recto ( $r$ ) or front page and the verso (v) or back page.

There were several production lines: The work commenced almost simultaneously with two composition lines (not necessarily two printing presses) working in parallel. To allow them to progress independently as much as possible, they started at distant points of the bible. Specifically, at quires I-1 and I-14. Very soon a third line joined, and then a fourth one, starting at quires II-1 and II-17, respectively (a division of work that shows good planning ahead). Still later on, possibly two new lines were deployed, although this is not universally accepted, and it is not relevant to our discussion here. For an up-to-date account of the printing chronology 
of the B42, we refer the reader to Rangel and Alabert [12]. The chronological table in Fig. 1 of [12] has a more readable and coloured version in [10, page 519].

It is assumed throughout the literature that the pages were printed, within each quire, in the natural reading order. This is disputable (see Schwab et al. [18] and Rangel and Alabert [12, section 3] for other options, compatible with all known facts related to the increase of edition), but it is again not relevant here; it is safe to assume the natural order in the sequel.

Gutenberg's workshop started composing and printing pages of the bible with a total edition size in mind; it is clear that, for efficiency reasons, once a page was composed (all metal types correctly arranged in the so-called form, or forme) all copies of that page would be printed before removing the types. The total number of printed copies of each page must coincide with the total number of books that were intended to print.

When the increase of edition was decided, 155 pages out of the total of 1275 were already printed. Three of the four production lines had some quires partially printed, namely,

- Quire I-4, pages 1r, 1v, 2r.

- Quire II-2, pages 1r to 6r.

- Quire II-17, page 1r.

In fact, all three lines had partially printed sheets: The second, the fifth, and the first, respectively. All these quires are standard 20-page quires as in Figure 1.

To increase the total print run, blank sheets had to be carried to the presses, printed only in the complementary pages $(2 \mathrm{v}, 9 \mathrm{r}, 9 \mathrm{v}$ of quire I-4; $6 \mathrm{v}$ of quire II; and $1 \mathrm{v}, 10 \mathrm{r}, 10 \mathrm{v}$ of quire II- 17$)$, and then left on hold. The second setting of the first pages was printed much time later, after the initially intended print run was ready to be sold. This is confirmed by the paper watermarks, belonging to a stock of late use. Hence, when those sheets went again to press, the forms had to be filled with a new setting for the missing pages.

As already mentioned, the bibles were sold in collections of quires. Therefore, it was perfectly possible that a particular book contained quires belonging to different settings. In fact, from the 35 bible copies that conserve all ten quires involved, 22 of them mix quires of both settings, and the remaining 13 are exclusively from the first setting.

Mixing both settings in the same quire was far more rare. Given the point of the increase of edition, this mixing could occur only in quires I-1, I-2, I-3 (possible with any of their five sheets, but with only one case observed in the surviving quires), I-4 (only possible within the two first sheets, no cases), I-14, I-15, I-16 (possible with all five sheets, two cases observed), and II-1 and II-2 (all five sheets, six cases observed).

\section{The strange case of quire II-2}

Perhaps the most perplexing fact in the collection of surviving copies of the 42-line bible is that the six cases observed of a quire with mixed sheets in volume II correspond all of them to quire II-2, and follow the same pattern: Sheets 1 to 4 are from the first setting, whereas the central sheet is from the second setting. Moreover, there is no surviving quire showing the reciprocal situation, with the central sheet from first setting, and the other four from the second. The probability that this happened by pure chance is extremely low.

We agree with Needham [9, section 4$]$ in that the only reasonable explanation is that, when the first page of sheet 5 was to be printed, a fewer number than usual of blank sheets were 
sent to the press. Pages $5 \mathrm{r}, 5 \mathrm{v}, 6 \mathrm{r}$ were printed in this reduced quantity. Then, page $6 \mathrm{v}$ was printed in a regular quantity, bringing in a certain number of new blank sheets, to complete the intended initial print run, and finally in some additional blank sheets, to arrive to the increased final print run. Towards the end of the works, all the incomplete sheets were sent back to the press to print again pages $5 \mathrm{r}, 5 \mathrm{v}, 6 \mathrm{r}$. Since these pages had to be typesetted again, they of course show the second setting.

Paul Needham attributes the accident of quire II-2 to a human error. This is possible indeed, but it should have been detected easily. From the 28 surviving quires, 6 show the mixed pattern. This gives an estimate of around $22 \%$ less sheets prepared for printing. The staff at charge of the printing press must have noticed, if nothing else, a notable reduction in printing time for page 5r. Moreover, the error would not be discovered at least until the third page was finished, and its form dismantled; otherwise blank sheets would have been brought in immediately and printed still with the first setting.

Given the high level of planning and control shown in other aspects, we think that a human error is unlikely, and we propose here another possible explanation: could a temporal shortage of paper supply have led to print this particular sheet in a lesser quantity? Even knowing that sheet 5 will be printed in a reduced quantity, it was anyway better to keep on printing, in view to have a number of books finished as soon as possible. Perhaps this paper shortage could be the responsible of a full stop of the works for one or more days, and triggered a rethinking of the total print run by Fust and Gutenberg. When the new supply arrived, page 6v could have been continued with the composition still in the form, and then all the incomplete sheets kept on hold until later.

Furthermore, Needham's study of the watermarks [9] seems to show that around the increase of edition point, paper with different watermarks started to be used, perhaps corresponding to a different batch.

Either the result of a human error or due to a paper shortage, for the purpose of estimating the increase of edition, all these mixed quires II- 2 must be considered as pure first setting quires. Indeed, they would have been first setting if the printing would have followed its normal pace. This is additionally supported by the rarity of mixed quires in general, the fact that no "complementary mixing" has been observed in this quire, and that doing so the proportion of first and second settings in pure quires coincides exactly with that of quire II-1 and it is very similar to the other quires presenting no mixtures.

\section{The Widener and Huntington copies}

One of the mistakes in the B42 censuses involves copy P24, property of the Widener Library in Harvard University, and was discovered and reported by Schwab et al. [18], while examining that copy for other purposes. In a series of papers, the historian Richard Schwab and his collaborators in the Physics Department of the University of California, Davis, analysed the ink of several copies of the B42, and other contemporary documents, by means of the "Proton-Induced X-ray Emission" (PIXE) technique, also referred as Proton Milliprobe (see [20], [19], [16], [17], [18], [14], [8] for the results, and [7], [3], and [15] for an explanation of this application of PIXE).

This technique allows to determine the relevant chemical elements present in the specimen analysed, and it was applied to make adjustments to the chronological table first published by Schwenke [20]. In [12], the table is further refined making use of an alignment technique similar to that used for the alignment of DNA sequences.

We agree with Teigen [21] in that the conclusions of these analyses must be taken with caution. The samples were small and the variability of the measures too big. However, a more 
thorough ink analysis is unlikely to take place in the near future, because of the logistic and economic effort involved. Until new evidence is found, the contributions of Schwab and the Davis physicists team are certainly valuable.

While Schwab's team was examining the Widener copy, they noticed that the composition of the ink in pages $5 \mathrm{r}, 5 \mathrm{v}$, $6 \mathrm{r}$ of quire II- 2 were very different from those of the surrounding pages and from those of the concurrent pages that were being printed in the other production lines. The ink seemed to indicate that the Widener pages were printed much later. Upon visual examination they realised that the pages did actually belong to the second setting, whereas the Schwenke census reported them as belonging to the first. Needham census was published two years before Schwab's paper, and therefore could not take this discovery into account.

But the observation by Schwab went unnoticed and the classification mistake is reproduced in White's book, and it is also present in Füssel [5], the recent booklet accompanying an excellent facsimile edition of the perfect vellum copy in the Niedersächsische Staats- und Universitätsbibliothek Göttingen.

In the same paper [18], while pointing out the error in the Widener copy, the authors somewhat mysteriously inserted the sentence "Most of the surveys erroneously record that pages of the second setting are also found on sheet 5 of quire II-2 in the Huntington Library vellum copy". No reference or personal witnessing is given to support this claim, and we have not been able to find in the literature any other comment on this fact. Moreover, White's census again assigns these pages to the second setting, as previously did Schwenke, Hubay, and Needham.

In this state of things, we were eager to check the setting by ourselves, and asked for help to the Huntington Library. Curator of rare books Stephen Tabor kindly took and sent us accurate photographs of the three pages. It turned out that Schwab was right. In Figure 2, we have reproduced a fragment of page II- $2-5 \mathrm{v}$ of the Huntington's copy, in the middle, together with corresponding fragments from the Göttingen copy (first setting, on top), and that of the Harry Ransom Center of the University of Texas, Austin (second setting, bottom).

As can be seen, there is no difficulty in attributing a page to one of the settings when it is confronted to given models. Differences in the first column are subtle; but the seven lines of the second column show manifest differences, the most noticeable of which are in the first line: In the first setting, the line starts and ends with the complete words inter and dilectus meus, whereas in the second it starts with a part of the previous word malus and ends in an abbreviated form of dilectus and meus. Differences can also be appreciated in the spacing, specially around the colons (:).

To be rigorous in assigning settings, one must be aware that there can be small differences in different copies of pages with the same setting, due to stop-press variants (see Agata [1], [2]). This is absolutely not the case here.

The fragments in the figure correspond to the beginning of the Canticum Canticorum Salomonis. According to White [22], the rich illuminations of the first two (printed in vellum) were done in Leipzig and Mainz respectively. The one of Austin (printed in paper) is much more modest, as it could have been acquired by a monastery and illuminated by the monks themselves.

Why these misclassifications ocurred in the first place? Are they related somehow? In a personal communication, Dr. White pointed us a very likely explanation: Paul Schwenke did not examined the Widener and Huntington copies himself, but instead he received the information, in the first decade of the XXth century, from the same source, the American printing-press manufacturer Robert Hoe, owner of both copies at that time (see Schwenke [20, p. 18, note 2]. Possibly, Mr. Hoe confused the models of first and second settings when examining that particular quire with both bibles open, and produced the two mistakes at the same time. 

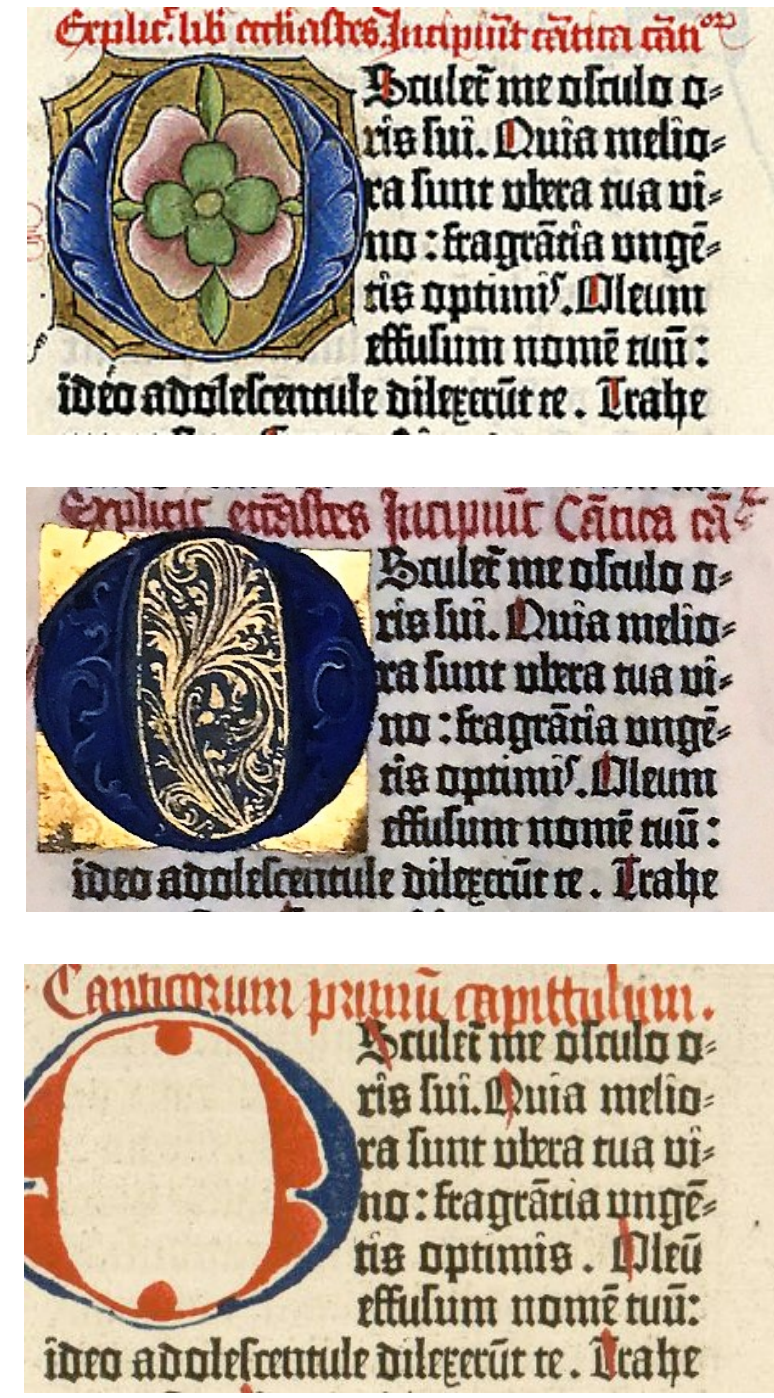

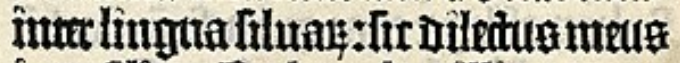
inter filiog. Toub unbraillints quent

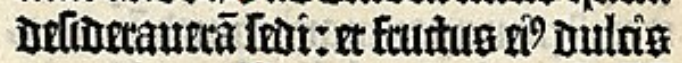
futturimeo. Inttoinuxit me rete ir rellä vìnariā : ozimuauti in me raritateur. frultite me floribs- Itipate me malis: quita ammre lauguro. Iruati lub ra=

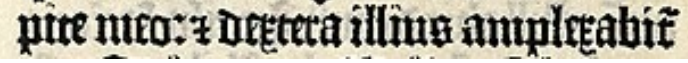

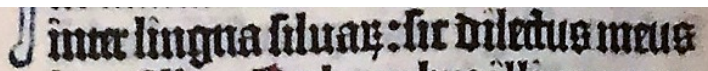
inter filiog. Bub mombrailling quen

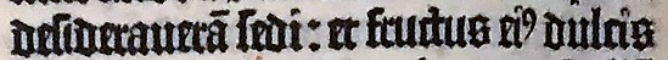
gutturi mo. Introinuxit me rę̧ irellä

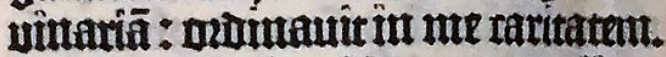
fulrite me tlaribs. Atipate me malis: quia amore lamguro. Uleuario futh ra:

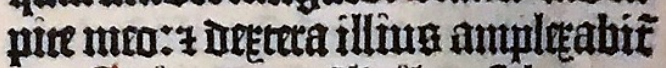

Lus intet ligua filuag: : frc Dilect9 me? inter filiogr. Sub umbra illiug quem

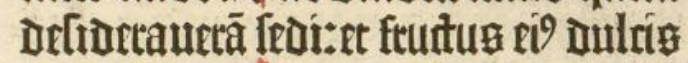

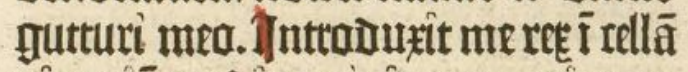
vinariā: modinaut in me raritatem. f fulrite me flaribs. Itipate me malis: quia amore langueo. Jeua eio fub ra pite meo: 7 ireteteta illius am pleEabif

Figure 2: From top to bottom: Göttingen (first setting), Huntington (also first setting), and Austin (second settting).

\section{Acknowledgments}

This work has been partially supported by grant number 2017-SGR-1094 from the Ministry of Business and Knowledge of Catalonia.

We would like to acknowledge specially Dr. Stephen Tabor, curator of the Huntington library, and the associate director Dr. Claudia Funke, for their kind help. Dr. Tabor provided nice photographs of quire II-2 of the Huntington copy, which allowed us to determine without any doubt that the whole quire was from the first setting.

We also want to acknowledge the help of Dr. Eric White, who commented a first version of this paper and provided us with the consistent explanation of the origin of the errors in the Schwenke census, given in Section 4.

\section{References}

[1] Mari Agata. Stop-press variants in the Gutenberg Bible: The first report of the collation. The Papers of the Bibliographical Society of America, 97(2):139-165, 2003. 
[2] Mari Agata. Stop-press variants in the Gutenberg Bible. PhD thesis, Keio University, 2007.

[3] T. A. Cahill, B. H. Kusko, R. A. Eldred, and R. N. Schwab. Gutenberg's inks and papers: Non-destructive compositional analyses by porton milliprobe. Archaeometry, 26(1):3-14, 1984.

[4] Seymour de Ricci. Catalogue raisonné des premières impressions de Mayence (1445-1467). Die Gesellschaft, 1911.

[5] Stephan Füssel. The Gutenberg Bible of 1454. Taschen, 2018.

[6] Ilona Hubay. Die bekannten exemplare der zweiundvierzigzeiligen bibel und ihre besitzer. In W. Schmidt and F. A. Schmidt-Künsemüller, editors, Johannes Gutenbergs zweiundvierzigzeilige Bibel, Faksimile-Ausgabe nach dem Exemplar der Staatsbibliothek preußischer Kulturbesitz Berlin: Kommentarband, pages 127-155. Idion Verlag, 1979.

[7] Bruce H. Kusko, Thomas A. Cahill, Robert A. Eldred, and Richard N. Schwab. Proton milliprobe analyses of the gutenberg bible. Nuclear Instruments and Methods in Physics Research Section B: Beam Interactions with Materials and Atoms, 3(1):689 - 694, 1984.

[8] Paul Needham. Division of copy in the Gutenberg bible: Three glosses on the ink evidence. The Papers of the Bibliographical Society of America, 79(3):pp. 411-426, 1985.

[9] Paul Needham. The paper supply of the Gutenberg bible. The Papers of the Bibliographical Society of America, 79(3):pp. 303-374, 1985.

[10] Luz M. Rangel. Del arte de imprimir o la Biblia de 42 líneas: aportaciones de un estudio crítico. PhD thesis, University of Barcelona, http://hdl . handle.net/10803/81829, 2011.

[11] Luz M. Rangel. El arte de imprimir. Universidad Iberoamericana A.C., 2020.

[12] Luz M. Rangel and Aureli Alabert. Printing chronology of the 42-line bible. An update. Gutenberg Jahrbuch, 87:53-70, 2012.

[13] Gustav Freiherr Schenk zu Schweinsberg. Genealogie des Mainzer Geschlechtes Gänsfleisch. In Otto Hartwig, editor, Festschrift zum funfhundertjährigen Geburtstage von Johann Gutenberg, page 80-162. Otto Harrassowitz, 1900.

[14] Richard N. Schwab. An "ersatz" leaf in the doheny gutenberg bible volume i. The Papers of the Bibliographical Society of America, 81:479, 1987. Última actualización - 2013-02-24.

[15] Richard N. Schwab. The history of the book and the proton milliprobe: An application of the the pixe technique of analysis. Library Trends, 36:53-84, 1987.

[16] Richard N. Schwab, Thomas A. Cahill, Robert A. Eldred, Bruce H. Kusko, and Daniel L. Wick. New evidence on the printing of the gutenberg bible: The inks in the doheny copy. The Papers of the Bibliographical Society of America, 79(3):375-410, 1985.

[17] Richard N. Schwab, Thomas A. Cahill, Bruce H. Kusko, Robert A. Eldred, and Daniel L. Wick. Ink patterns in the gutenberg new testament: The proton milliprobe analysis of the lilly library copy. The Papers of the Bibliographical Society of America, 80(3):305-331, 1986.

[18] Richard N. Schwab, Thomas A. Cahill, Bruce H. Kusko, Robert A. Eldred, and Daniel L. Wick. The proton milliprobe ink analysis of the Harvard b42, volume II. The Papers of the Bibliographical Society of America, 81:403, 1987. Última actualización - 2013-02-24. 
[19] Richard N. Schwab, Thomas A. Cahill, Bruce H. Kusko, and Daniel L. Wick. Cyclotron analysis of the ink in the 42-line bible. The Papers of the Bibliographical Society of America, 77(3):pp. 285-315, 1983.

[20] Paul Schwenke. Die Gutenbergbibel. In Johannes Gutenbergs zweiundvierzigzeilige Bibel: Ergänzungsband zur Faksimile-Ausgabe. Iminsel, Leipzig 1923.

[21] Philip M. Teigen. Concurrent printing of the gutenberg bible and the proton milliprobe analysis of its ink. The Papers of the Bibliographical Society of America, 87(4):437-451, 1993.

[22] Eric Marshall White. Editio princeps : a history of the Gutenberg Bible. Harvey Miller studies in the history of culture. Harvey Miller Publishers, 2017. 